\title{
Alkaline hydrolysis to remove potentially infectious viral RNA contaminants from DNA
}

\author{
Karissa A. Lemire, Yelitza Y. Rodriguez and Michael T. McIntosh*
}

\begin{abstract}
Background: Diagnostics and research of high-consequence animal disease agents is often limited to laboratories with a high level of biosecurity that restrict the transport of biological material. Often, sharing of DNA with external partners is needed to support diagnostics, forensics, or research. Even in the absence of virus, RNA from positive-sense single stranded RNA (+ssRNA) viruses that may contaminate otherwise purified DNA preparations continues to pose a threat due to its potential to be infectious via direct translation to yield viral proteins. While the risk of animal infection or accidental reconstitution and release of a virus from RNA is very low, the high impact of an animal disease event associated with the accidental release of some + ssRNA viruses, such as classical swine fever or foot-and-mouth disease viruses, necessitates the precaution of having procedures to ensure the complete inactivation of viruses and + ssRNA viral genomes. RNA and DNA are differentially susceptible to enzymatic degradations; however, such procedures are susceptible to unintended DNA damage and/or failure due to enzyme or cofactor instabilities. Therefore, we describe the development and verification of a robust and simple chemical and physical method to selectively degrade RNA from purified DNA preparations. The procedure employs incubation of DNA in $0.25 \mathrm{~N}$ sodium hydroxide at $65^{\circ} \mathrm{C}$ for $1 \mathrm{~h}$ followed by neutralization and boiling for 10 min to hydrolyze contaminating RNA and inactivate animal disease viruses from DNA preparations. Additional critical quality control elements include use of a synthetic control RNA (SCR) and an SCR-specific real-time RT-PCR to track effectiveness of the procedure in a parallel treated control sample, and a pH check of reagents to ensure proper neutralization of alkaline conditions.
\end{abstract}

Results: The new procedure reduced intact RNA beyond the limit of detection by realtime RT-PCR and inactivated viruses by in vitro culture infectivity assays.

Conclusions: Treated DNA, while denatured, remains suitable for most common molecular biology procedures including $\mathrm{PCR}$, transformation of E. coli, and molecular sequencing. The procedure ensures not only the inactivation of a variety of viruses but also the degradation through hydrolysis of potentially contaminating infectious + ssRNA viral genomes.

\section{Background}

Positive-sense single stranded RNA (+ssRNA) viruses of agricultural and economic importance include agents such as foot-and-mouth disease virus (FMDV) and classical swine fever virus (CSFV). FMDV is a highly contagious disease of cloven-hoofed animals including cattle, swine, sheep, goats, and various wildlife species. FMDV is a non-enveloped virus belonging to the genus

\footnotetext{
* Correspondence: michael.t.mcintosh@aphis.usda.gov

Foreign Animal Disease Diagnostic Laboratory, NVSL, STAS, VS, APHIS, USDA, Plum Island Animal Disease Center, PO Box 848, Greenport, NY 11944-0848, USA
}

(c) 2016 The Author(s). Open Access This article is distributed under the terms of the Creative Commons Attribution 4.0 International License (http://creativecommons.org/licenses/by/4.0/), which permits unrestricted use, distribution, and reproduction in any medium, provided you give appropriate credit to the original author(s) and the source, provide a link to the Creative Commons license, and indicate if changes were made. The Creative Commons Public Domain Dedication waiver (http://creativecommons.org/publicdomain/zero/1.0/) applies to the data made available in this article, unless otherwise stated. seven known serotypes of FMDV including types A, O, C, Asia1, South African Territories (SAT) 1, SAT2, and SAT3 [1]. Although mortality in adult animals is low, its wide distribution, high transmission rates, and broad host range in livestock make it one of the leading threats to animal agriculture, reviewed in [2]. CSFV is another highly contagious disease of livestock, affecting specifically swine and wild boars, and belonging to the genus Pestivirus in the family Flaviviridae [3]. Although there is only one known serotype of CSFV, several strains ranging in virulence have been identified, some with high 
mortality rates, reviewed in [4]. Both FMDV and CSFV can result in high-consequence animal disease outbreaks with significant economic losses in livestock industries and trade and are reportable to the World Organization of Animal Health (OIE). Consequently, diagnostics and research on such high-consequence animal disease pathogens is typically limited to laboratories with a high level of biosecurity and restricted permissible transport of biological materials out of the laboratory. Such precautions include the export of purified nucleic acids.

Even in the absence of virus, RNA from + ssRNA viruses continues to pose a threat to agricultural industries due to its potential to be infectious via direct translation yielding viral proteins [5]. For instance, transfection studies employing DNA contaminated with RNA from + ssRNA viruses can inadvertently result in the expression of infectious virus. Often, however, the sharing of DNA with external partner laboratories is needed to support diagnostics, forensics, or research and development activities. For example, non-infectious DNA samples, such as human DNA associated with forensic samples from an animal disease investigation, might need to be shared with a criminal investigation laboratory. Alternately, a portion of complementary DNA (cDNA) or DNA from a virus may need to be sent, either directly or cloned into plasmid DNA, to another laboratory as an experimental reagent. Because these DNA materials originate from a biocontainment laboratory that works with + ssRNA viruses of high-consequence, trace amounts of virus or even viral RNA present concerning sources of potentially infectious contamination that must be mitigated prior to the transport of DNA outside of biocontainment.

Due to subtle differences in the structures of RNA and DNA, including a hydroxyl group on the 2'-carbon atom of the phosphopentose backbone of RNA, RNA reactivity and stability under certain conditions is fundamentally different than that of DNA [6]. For example in the early 1900's, shortly after the discovery of RNA and DNA, the instability of RNA and contrasting stability of DNA under basic conditions was recognized. This fundamental biochemical property of RNA formed the basis of widely established alkaline treatment methods for the purification of free or partially hydrolyzed ribonucleotides from RNA [7], and modern methods of degrading RNA in labeling or stripping of DNA microarrays or in advanced molecular sequencing protocols [8-11]. In contrast, the stability of ssDNA under alkaline conditions formed the basis for the alkaline lysis method of plasmid DNA purification from bacteria [12]. RNA is uniquely unstable in alkaline conditions because bases can easily deprotonate the hydrogen from the hydroxyl group on the 2'-carbon atom (Fig. 1). This deprotonation causes the oxygen to become negatively charged leading to a nucleophilic attack on the adjacent phosphate atom leading to the cleavage of the phosphopentose backbone of RNA. The resultant 2',3'-cyclic phosphate is further hydrolyzed to $2^{\prime}$ or to $3^{\prime}$ phosphate leaving RNA fragments or free ribonucleotides with 5'-OH and 3'-

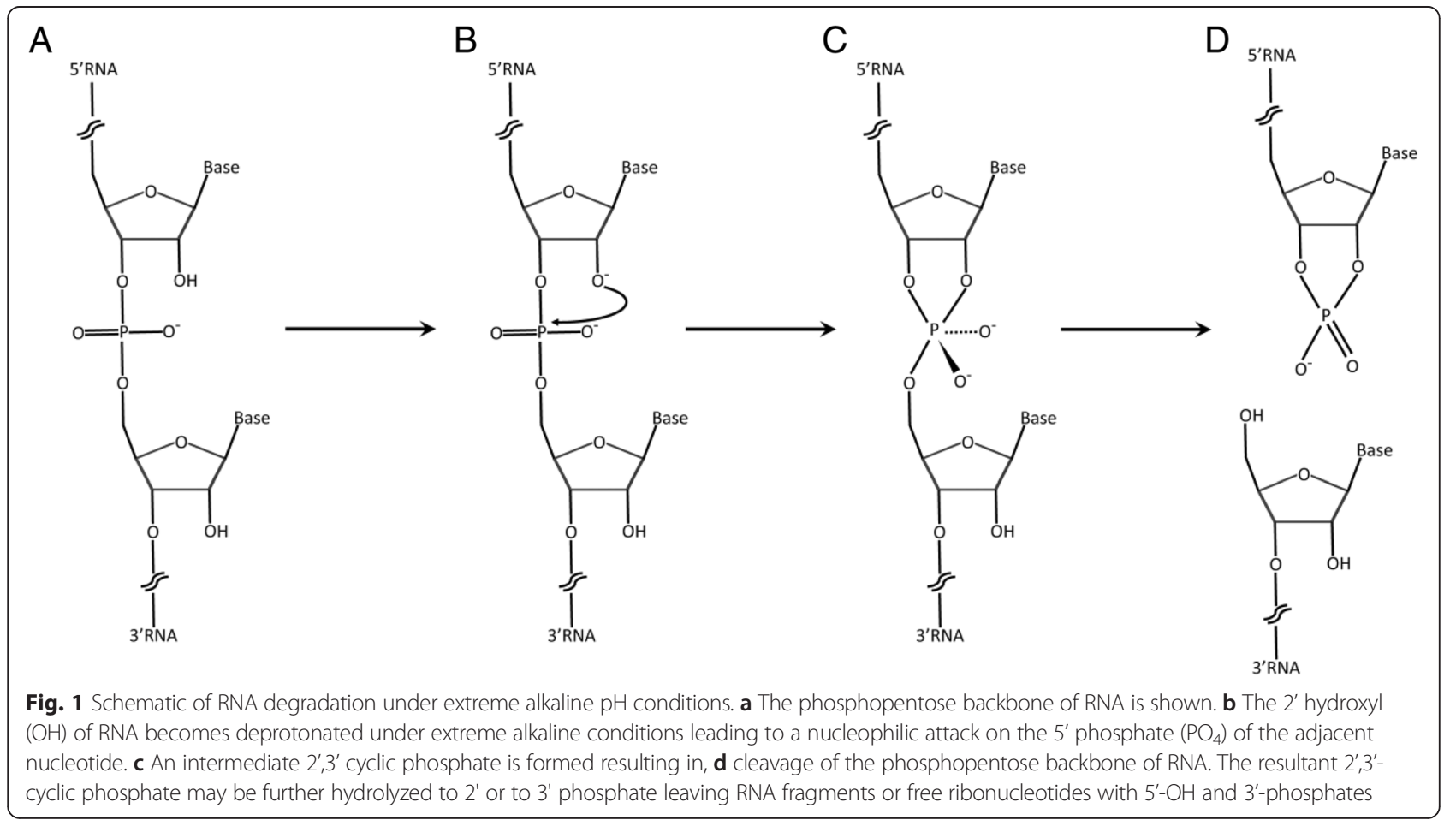


phosphates, depending on the level of degradation (Fig. 1). Conversely the lack of a 2'-OH in DNA prevents cleavage of the phosphate backbone making DNA relatively stable at high $\mathrm{pH}$. As this autocatalytic degradation is a property of the RNA phosphopentose backbone itself, the use of alkaline $\mathrm{pH}$ combined with heat treatment has been used to selectively degrade RNA from RNA:DNA or RNA:cDNA hybrids [10, 11, 13].

While RNA and DNA are also differentially susceptible to enzymatic degradations, such procedures may cause unintended DNA damage and/or fail due to enzyme or cofactor instabilities. This paper aims to describe the development and verification of a robust and simple chemical method to selectively degrade RNA. The procedure is demonstrated to be useful in the inactivation of viruses and the removal of RNA, including potentially infectious viral + ssRNA, from a purified DNA sample. Extreme alkaline $(0.25 \mathrm{~N} \mathrm{NaOH}$ at $\mathrm{pH}>12)$ and heat treatment were chosen as the basis of the new DNA safety treatment method based on the well-established property of RNA degradation and ssDNA stability under alkaline conditions, previously established sensitivity of high-consequence animal disease viruses to heat inactivation by boiling for $5 \mathrm{~min}$, and documented inactivation of FMDV and CSFV at alkaline pH. In this regard, FMDV is inactivated at $\mathrm{pH}$ levels less than 6 and greater than 9 [14], and CSFV is known to be inactivated at $\mathrm{pH}$ levels less than 3 and greater than 11 [15]. While alkaline or heat treatment are both individually expected to denature dsDNA, this procedure, based on the verification studies presented herein and earlier studies on heat inactivation of animal disease viruses [16, 17], may form the basis for inactivation of potentially contaminating viruses and the robust degradation of viral + ssRNA from purified DNA. Following alkaline and heat treatment, the denatured DNA remains suitable for recovery by precipitation and manipulation in routine molecular biology procedures such as transformation of E.coli and molecular sequencing.

\section{Results}

\section{DNA integrity and loss of RNA}

Integrity of DNA, such that safety treated DNA remains intact, unmodified, and suitable for manipulation in most routine molecular biology procedures, was an important criteria in the development of the alkaline and heat DNA safety treatment procedure. While, alkaline and heat treatment are both individually expected to denature dsDNA, confirming minimal single stranded nicks and double strand breaks was deemed important for downstream applications such as bacterial transformation of plasmids, PCR, and DNA sequencing.

DNA integrity and loss of RNA was evaluated by agarose gel electrophoresis, rRT-PCR, and sequencing. Various samples including, plasmid and/or CSFV and African swine fever virus (ASFV) PCR amplified cDNA or DNA, CSFV RNA, and/or synthetic control RNA (SCR) spiked samples after $\mathrm{NaOH}$ and heat treatment, heat treatment alone, or no treatment as control were evaluated.

Table 1 addresses initial studies aimed at verification of RNA degradation while maintaining plasmid DNA integrity using a $\mathrm{NaOH}$ and heat treatment incubation time of $30 \mathrm{~min}$ as compared to the later determined optimal treatment time of $60 \mathrm{~min}$. CSFV RNA and SCR spiked samples containing plasmid DNA were tested in various conditions ranging from untreated control samples to safety treated plasmid DNA samples containing SCR as an internal control and CSFV RNA as a simulated contaminant (Table 1). All positive controls (untreated, heat only treatment, or $250 \mathrm{mM} \mathrm{NaCl}$ containing samples) for both SCR RNA and CSFV RNA tested positive by rRT-PCR for their respective targets (Table 1). All negative controls (water or samples with no target added) tested negative for SCR and CSFV RNA by rRT-PCR (Table 1). All safety treated samples tested negative by SCR and CSF rRT-PCRs for their respective targets with the exception of sample 4, suggesting that the time of incubation for $\mathrm{NaOH}$ and heat treatment could be further optimized. Plasmid DNA integrity was maintained with some slight nicking and denaturation to ssDNA as visualized by agarose gel electrophoresis (data not shown).

Table 2 and Fig. 2 address safety treatment optimization studies aimed at verifying SCR degradation while maintaining viral and plasmid DNA integrity using $\mathrm{NaOH}$ and heat treatment incubation times of 30, 45 and $60 \mathrm{~min}$. CSFV cDNA, plasmid and ASFV DNA samples were tested in various conditions ranging from untreated control samples to safety treated DNA samples all containing SCR internal controls (Table 2). All positive controls (untreated, heat only treatment or diluted samples) tested positive by SCR rRT-PCR. SCR was not degraded beyond the level of rRT-PCR detection during the safety treatment process for the 30 and 45 min incubations at $65{ }^{\circ} \mathrm{C}$ in $0.25 \mathrm{~N} \mathrm{NaOH}$ as indicated by positive SCR rRT-PCR results (Table 2). All SCR RNA samples incubated for $60 \mathrm{~min}$ at $65{ }^{\circ} \mathrm{C}$ tested negative for SCR RNA by rRT-PCR (Table 2).

All ASFV DNA samples, controls and treatment samples retained intact DNA. This was verified by ASF rPCR in all samples, with the exception of samples 10 and 13 that yielded anomalous rPCR amplification dynamics due to high ASFV DNA template concentrations (Table 2). All CSFV cDNA samples likewise tested positive by CSF rRT$\mathrm{PCR}$, indicating DNA integrity was maintained throughout the process (Table 2). Plasmid DNA integrity was maintained with some slight nicking and/or denaturation of ssDNA as indicated by supercoiled untreated plasmid 
Table 1 Verification of RNA degradation while maintaining plasmid DNA integrity

\begin{tabular}{|c|c|c|c|c|c|c|c|c|c|}
\hline Sample ID & Heat & Plasmid & CSFV RNA & SCR & $\mathrm{NaOH}$ & $\mathrm{HCl}$ & $\mathrm{TE}$ & PCR & DNA \\
\hline 1- SCR RNA & $x$ & $0 \mu \mathrm{l}$ & $0 \mu \mathrm{l}$ & $26 \mu \mathrm{l}$ & $0 \mu \mathrm{l}$ & $0 \mu \mathrm{l}$ & $260 \mu l$ & $\mathrm{SCR}+, \mathrm{CSF}-$ & NA \\
\hline 2- Plasmid DNA & $x$ & $130 \mu \mathrm{l}$ & $0 \mu \mathrm{l}$ & $0 \mu \mathrm{l}$ & $0 \mu \mathrm{l}$ & $0 \mu \mathrm{l}$ & $156 \mu l$ & SCR-, CSF- & + \\
\hline 3- SCR RNA/Plasmid DNA & $x$ & $130 \mu \mathrm{l}$ & $0 \mu \mathrm{l}$ & $26 \mu \mathrm{l}$ & $0 \mu \mathrm{l}$ & $0 \mu \mathrm{l}$ & $130 \mu l$ & $\mathrm{SCR}+, \mathrm{CSF}-$ & + \\
\hline 4- SCR RNA treated & $x$ & $0 \mu \mathrm{l}$ & $0 \mu \mathrm{l}$ & $26 \mu \mathrm{l}$ & $60 \mu \mathrm{l}$ & $60 \mu \mathrm{l}$ & $140 \mu \mathrm{l}$ & SCR+, CSF- & NA \\
\hline 5- Plasmid DNA treated & $x$ & $130 \mu l$ & $0 \mu \mathrm{l}$ & $0 \mu \mathrm{l}$ & $60 \mu \mathrm{l}$ & $60 \mu \mathrm{l}$ & $36 \mu \mathrm{l}$ & SCR-, CSF- & $t^{\mathrm{a}}$ \\
\hline 6- SCR RNA/Plasmid DNA treated & $x$ & $130 \mu \mathrm{l}$ & $0 \mu \mathrm{l}$ & $26 \mu \mathrm{l}$ & $60 \mu \mathrm{l}$ & $60 \mu \mathrm{l}$ & $10 \mu \mathrm{l}$ & SCR-, CSF- & $t^{\mathrm{a}}$ \\
\hline 7- CSF RNA & $x$ & $0 \mu \mathrm{l}$ & $10 \mu \mathrm{l}$ & $0 \mu \mathrm{l}$ & $0 \mu \mathrm{l}$ & $0 \mu \mathrm{l}$ & $276 \mu l$ & SCR-, CSF+ & NA \\
\hline 8- CSF RNA/SCR RNA & $x$ & $0 \mu \mathrm{l}$ & $10 \mu \mathrm{l}$ & $26 \mu \mathrm{l}$ & $0 \mu \mathrm{l}$ & $0 \mu \mathrm{l}$ & $250 \mu \mathrm{l}$ & SCR+, CSF+ & NA \\
\hline 9- CSF RNA/SCR RNA/ Plasmid DNA & $x$ & $130 \mu \mathrm{l}$ & $10 \mu \mathrm{l}$ & $26 \mu l$ & $0 \mu \mathrm{l}$ & $0 \mu \mathrm{l}$ & $166 \mu l$ & $\mathrm{SCR}+, \mathrm{CSF}+$ & + \\
\hline 10- CSF RNA/Plasmid DNA & $x$ & $130 \mu l$ & $10 \mu \mathrm{l}$ & $0 \mu \mathrm{l}$ & $0 \mu \mathrm{l}$ & $0 \mu \mathrm{l}$ & $140 \mu \mathrm{l}$ & SCR-, CSF+ & + \\
\hline 11- CSF RNA treated & $x$ & $0 \mu \mathrm{l}$ & $10 \mu \mathrm{l}$ & $0 \mu \mathrm{l}$ & $60 \mu \mathrm{l}$ & $60 \mu \mathrm{l}$ & $130 \mu \mathrm{l}$ & SCR-, CSF- & NA \\
\hline 12- CSF RNA/SCR RNA treated & $x$ & $0 \mu \mathrm{l}$ & $10 \mu \mathrm{l}$ & $26 \mu \mathrm{l}$ & $60 \mu \mathrm{l}$ & $60 \mu \mathrm{l}$ & $156 \mu l$ & SCR-, CSF- & NA \\
\hline 13- CSF RNA/SCR RNA/ Plasmid DNA treated & $x$ & $130 \mu \mathrm{l}$ & $10 \mu \mathrm{l}$ & $26 \mu \mathrm{l}$ & $60 \mu \mathrm{l}$ & $60 \mu \mathrm{l}$ & $0 \mu \mathrm{l}$ & SCR-, CSF- & $+^{\mathrm{a}}$ \\
\hline 14- CSF RNA/Plasmid DNA treated & $x$ & $130 \mu \mathrm{l}$ & $10 \mu \mathrm{l}$ & $0 \mu \mathrm{l}$ & $60 \mu \mathrm{l}$ & $60 \mu \mathrm{l}$ & $260 \mu \mathrm{l}$ & SCR-, CSF- & $t^{a}$ \\
\hline 15- SCR RNA post pH normalization & $x$ & $0 \mu l$ & $0 \mu l$ & $\left.26 \mu\right|^{b}$ & $60 \mu \mathrm{l}$ & $60 \mu \mathrm{l}$ & $146 \mu l$ & $\mathrm{SCR}+, \mathrm{CSF}-$ & NA \\
\hline 16- Plasmid DNA post pH normalization & $x$ & $130 \mu \mathrm{l}^{\mathrm{b}}$ & $0 \mu \mathrm{l}$ & $0 \mu \mathrm{l}$ & $60 \mu \mathrm{l}$ & $60 \mu \mathrm{l}$ & $36 \mu l$ & SCR-, CSF- & + \\
\hline 17- CSF RNA post pH normalization & $x$ & $0 \mu \mathrm{l}$ & $\left.10 \mu\right|^{b}$ & $0 \mu \mathrm{l}$ & $60 \mu \mathrm{l}$ & $60 \mu \mathrm{l}$ & $130 \mu \mathrm{l}$ & SCR-, CSF+ & NA \\
\hline 18- CSF RNA/SCR RNA post pH normalization & $x$ & $0 \mu \mathrm{l}$ & $\left.10 \mu\right|^{b}$ & $\left.26 \mu\right|^{b}$ & $60 \mu \mathrm{l}$ & $60 \mu \mathrm{l}$ & $156 \mu \mathrm{l}$ & $\mathrm{SCR}+, \mathrm{CSF}+$ & NA \\
\hline 19- CSF RNA/SCR RNA/Plasmid DNA post pH normalization & $x$ & $\left.130 \mu\right|^{b}$ & $10 \mu 1^{b}$ & $\left.26 \mu\right|^{b}$ & $60 \mu \mathrm{l}$ & $60 \mu \mathrm{l}$ & $0 \mu \mathrm{l}$ & $\mathrm{SCR}+, \mathrm{CSF}+$ & + \\
\hline 20- CSF RNA undilute control & & $0 \mu l$ & $2.5 \mu l$ & $0 \mu \mathrm{l}$ & $0 \mu \mathrm{l}$ & $0 \mu \mathrm{l}$ & $0 \mu \mathrm{l}$ & SCR-, CSF+ & NA \\
\hline 21- CSF RNA diluted control & & $0 \mu \mathrm{l}$ & $10 \mu \mathrm{l}$ & $0 \mu \mathrm{l}$ & $0 \mu \mathrm{l}$ & $0 \mu l$ & $276 \mu l$ & SCR-, CSF+ & NA \\
\hline 22- SCR RNA diluted control & & $0 \mu \mathrm{l}$ & $0 \mu \mathrm{l}$ & $26 \mu \mathrm{l}$ & $0 \mu \mathrm{l}$ & $0 \mu \mathrm{l}$ & $260 \mu \mathrm{l}$ & SCR+, CSF- & NA \\
\hline 23- SCR RNA undilute control & & $0 \mu \mathrm{l}$ & $0 \mu \mathrm{l}$ & $2.5 \mu \mathrm{l}$ & $0 \mu \mathrm{l}$ & $0 \mu \mathrm{l}$ & $0 \mu \mathrm{l}$ & SCR+, CSF- & NA \\
\hline 24- CSF positive amplification control & & $0 \mu \mathrm{l}$ & $2.5 \mu l$ & $0 \mu \mathrm{l}$ & $0 \mu \mathrm{l}$ & $0 \mu \mathrm{l}$ & $0 \mu \mathrm{l}$ & SCR-, CSF+ & NA \\
\hline 25- No template control for PCR & & $0 \mu \mathrm{l}$ & $0 \mu \mathrm{l}$ & $0 \mu \mathrm{l}$ & $0 \mu \mathrm{l}$ & $0 \mu \mathrm{l}$ & $\mathrm{H}_{2} \mathrm{O}$ & SCR-, CSF- & NA \\
\hline
\end{tabular}

Samples, containing various combinations of SCR RNA, CSF RNA, and pGEM Teasy Vector plasmid, treatment conditions, and results for verification of RNA degradation and maintenance of plasmid DNA integrity are listed. $\mathrm{NaOH}$ and heat treatment incubation time used in this initial study was 30 min. ${ }^{\text {SSlight }}$ nicking

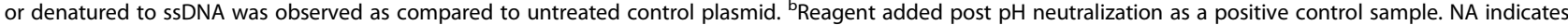
not analyzed; $\mathrm{x}$ indicates $60^{\circ} \mathrm{C}$ incubation and $10^{\prime}$ boiling steps were included

DNA and less sharp banding with slightly slow mobility on agarose gel electrophoresis (Fig. 2). No significant difference in the integrity of CSFV cDNA, plasmid, or ASFV DNA was apparent regardless of the time of incubation for alkaline hydrolysis; therefore, $60 \mathrm{~min}$ was selected as the optimal time of alkaline and heat hydrolysis to ensure complete degradation of all RNA (Table 2 and Fig. 2).

\section{Effects on bacterial transformations}

Transformation efficiency of alkali and heat treated DNA was evaluated using E. coli strains DH5 alpha, JM109, and BL21. Alkali and heat safety treated pBlueScript II plasmid, or untreated plasmid as control, were used to transform bacteria using a variation of the heat shock method [18]. Each bacterial strain readily yielded transformants, albeit efficiencies were reduced by 6.6 to 54.8 fold as compared to transformations with untreated plasmid. Blue white colony screening by alpha complementation was used with the DH5 alpha strain to demonstrate proper expression and function of the plasmid encoded LacZ gene product before and after alkali and heat safety treatment. In this regard, all bacterial DH5 alpha colonies were blue suggesting a lack of significant mutation leading to loss in expression or function of the alpha peptide of $\beta$-galactosidase.

\section{Sequencing of DNA post alkaline and heat hydrolysis of RNA}

FMDV cDNA integrity was analyzed by sequencing of the P1 region of the FMDV genome. Maintenance of DNA integrity is important to ensure successful performance of downstream applications. Table 3 and Fig. 3 address downstream application studies aimed at verification of DNA integrity by FMDV sequencing of the P1 region of the genome. FMDV cDNA samples were tested in various conditions ranging from untreated control 
Table 2 Optimization of RNA hydrolysis while maintaining viral and plasmid DNA integrity

\begin{tabular}{|c|c|c|c|c|c|c|c|c|c|c|}
\hline Sample ID & Heat (min) & DNA & SCR RNA & $\mathrm{NaOH}$ & $\mathrm{HCl}$ & TE & SCR PCR & ASF PCR & CSF PCR & DNA integrity \\
\hline 1- ASF DNA control & 0 & $35 \mu \mathrm{l}$ & $7 \mu l$ & $0 \mu \mathrm{l}$ & $0 \mu l$ & $30 \mu \mathrm{l}$ & + & + & NA & + \\
\hline 2- CSF DNA control & 0 & $35 \mu l$ & $7 \mu l$ & $0 \mu \mathrm{l}$ & $0 \mu \mathrm{l}$ & $30 \mu \mathrm{l}$ & + & NA & + & + \\
\hline 3- Plasmid DNA control & 0 & $35 \mu \mathrm{l}$ & $7 \mu l$ & $0 \mu \mathrm{l}$ & $0 \mu \mathrm{l}$ & $30 \mu \mathrm{l}$ & + & NA & NA & + \\
\hline 4- ASF DNA heated & 30 & $35 \mu l$ & $7 \mu l$ & $0 \mu \mathrm{l}$ & $0 \mu l$ & $30 \mu \mathrm{l}$ & + & + & NA & + \\
\hline 5- CSF DNA heated & 30 & $35 \mu l$ & $7 \mu l$ & $0 \mu \mathrm{l}$ & $0 \mu \mathrm{l}$ & $30 \mu \mathrm{l}$ & + & NA & + & + \\
\hline 6- Plasmid DNA heated & 30 & $35 \mu l$ & $7 \mu l$ & $0 \mu \mathrm{l}$ & $0 \mu l$ & $30 \mu \mathrm{l}$ & + & NA & NA & + \\
\hline 7- ASF DNA treated & 30 & $35 \mu l$ & $7 \mu l$ & $15 \mu l$ & $15 \mu \mathrm{l}$ & $0 \mu \mathrm{l}$ & - & + & NA & + \\
\hline 8- CSF DNA treated & 30 & $35 \mu l$ & $7 \mu l$ & $15 \mu l$ & $15 \mu \mathrm{l}$ & $0 \mu \mathrm{l}$ & + & NA & + & + \\
\hline 9- Plasmid DNA treated & 30 & $35 \mu l$ & $7 \mu l$ & $15 \mu \mathrm{l}$ & $15 \mu \mathrm{l}$ & $0 \mu \mathrm{l}$ & + & NA & NA & $+^{a}$ \\
\hline 10- ASF DNA treated & 45 & $35 \mu \mathrm{l}$ & $7 \mu l$ & $15 \mu \mathrm{l}$ & $15 \mu l$ & $0 \mu \mathrm{l}$ & - & $\ln c^{b}$ & NA & + \\
\hline 11- CSF DNA treated & 45 & $35 \mu l$ & $7 \mu l$ & $15 \mu l$ & $15 \mu \mathrm{l}$ & $0 \mu \mathrm{l}$ & + & NA & + & + \\
\hline 12- Plasmid DNA treated & 45 & $35 \mu l$ & $7 \mu l$ & $15 \mu l$ & $15 \mu \mathrm{l}$ & $0 \mu \mathrm{l}$ & - & NA & NA & $+^{a}$ \\
\hline 13- ASF DNA treated & 60 & $35 \mu l$ & $7 \mu l$ & $15 \mu l$ & $15 \mu \mathrm{l}$ & $0 \mu \mathrm{l}$ & - & $\ln c^{b}$ & NA & + \\
\hline 14- CSF DNA treated & 60 & $35 \mu l$ & $7 \mu l$ & $15 \mu \mathrm{l}$ & $15 \mu \mathrm{l}$ & $0 \mu \mathrm{l}$ & - & NA & + & + \\
\hline 15- Plasmid DNA treated & 60 & $35 \mu l$ & $7 \mu l$ & $15 \mu l$ & $15 \mu \mathrm{l}$ & $0 \mu \mathrm{l}$ & - & NA & NA & $+^{a}$ \\
\hline 16- SCR in TE & 0 & $0 \mu \mathrm{l}$ & $7 \mu l$ & $0 \mu l$ & $0 \mu \mathrm{l}$ & $65 \mu \mathrm{l}$ & + & NA & NA & NA \\
\hline 17- SCR in salt & 0 & $0 \mu \mathrm{l}$ & $7 \mu l$ & $\left.15 \mu\right|^{c}$ & $\left.15 \mu\right|^{c}$ & $35 \mu \mathrm{l}$ & + & NA & NA & NA \\
\hline 18- SCR undilute control & 0 & $0 \mu l$ & $2.5 \mu \mathrm{l}$ & $0 \mu \mathrm{l}$ & $0 \mu l$ & $0 \mu l$ & + & NA & NA & NA \\
\hline
\end{tabular}

Samples containing various combinations of ASF DNA, CSF CDNA, and plasmid DNA, under various treatment conditions. All samples contained SCR, and results for verification of SCR degradation and maintenance of plasmid DNA integrity are listed. $\mathrm{NaOH}$ and heat treatment incubation time used in this study range from 0 to $60 \mathrm{~min}$. Following heat treatment for various times at alkaline $\mathrm{pH}$, all samples were boiled for $10 \mathrm{~min}$ at neutral pH. ${ }^{\mathrm{a}} \mathrm{Slight}$ nicking or denatured ssDNA was observed as compared to untreated control plasmid. ${ }^{b}$ Inconclusive rPCR result (Inc) due to high concentration of DNA template. ${ }^{\mathrm{N}} \mathrm{Neutralized}$ salt solution (equal parts $1 \mathrm{~N} \mathrm{NaOH}$ and $1 \mathrm{~N} \mathrm{HCl}$ ) reagent used as a positive control. $\mathrm{NA}$ indicates not analyzed

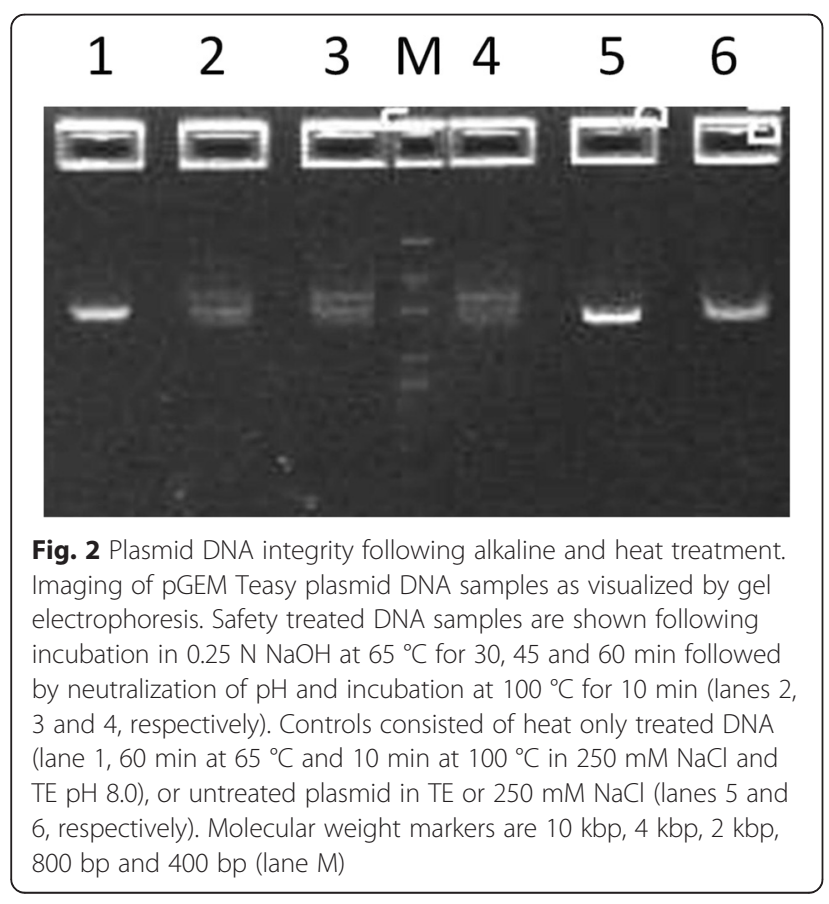

samples to safety treated DNA samples incubated at the optimized incubation time of $60 \mathrm{~min}$ (Table 3). All FMDV cDNA samples, including untreated, heat only treated, and alkali and heat treated samples were successfully sequenced at comparable coverage (Fig. 3). All high quality DNA sequences appeared to be identical in comparisons to untreated control FMDV cDNA.

\section{Inactivation of viruses post alkaline and heat hydrolysis of RNA or boiling}

Virus isolation was performed to ensure inactivation of FMDV and CSFV during the $\mathrm{NaOH}$ and heat DNA safety treatment process which included a final $10 \mathrm{~min}$ boiling step. Table 4 addresses studies aimed at verification of the inactivation of infectious FMDV and CSFV by heat only treatment $\left(65^{\circ} \mathrm{C}\right.$ for $1 \mathrm{~h}$ followed by boiling for $10 \mathrm{~min}$ ) or the complete $\mathrm{NaOH}$ and heat safety treatment using infectivity assays in primary LK or the SK-6 cell line, respectively. FMDV and CSFV spiked samples were tested under various conditions ranging from untreated, heat only and $\mathrm{NaOH}$ and heat safety treatment (Table 4). All positive controls (untreated and unheated, undilute or virus in diluents: TE, salt, or water) tested positive for cytopathic effect for FMDV and by immunohistochemical staining for CSFV (Table 4). All heat only 
Table 3 Effects of safety treatment on FMDV P1 cDNA sequencing applications

\begin{tabular}{|c|c|c|c|c|c|c|}
\hline Sample ID & Heat & SCR & $\mathrm{NaOH}$ & $\mathrm{HCl}$ & $\mathrm{TE} / \mathrm{H}_{2} \mathrm{O}$ & P1 Sequence \\
\hline 1- FMD P1 cDNA heated & $x$ & $0 \mu \mathrm{l}$ & $0 \mu \mathrm{l}$ & $0 \mu \mathrm{l}$ & $37 \mu \mathrm{l}$ & + \\
\hline 2- FMD P1 CDNA + SCR heated & $x$ & $7 \mu \mathrm{l}$ & $0 \mu \mathrm{l}$ & $0 \mu \mathrm{l}$ & $30 \mu \mathrm{l}$ & + \\
\hline 3- FMD P1 cDNA treated & $x$ & $0 \mu \mathrm{l}$ & $15 \mu \mathrm{l}$ & $15 \mu \mathrm{l}$ & $7 \mu \mathrm{l}$ & + \\
\hline 4- FMD P1 CDNA + SCR treated & $x$ & $7 \mu \mathrm{l}$ & $15 \mu \mathrm{l}$ & $15 \mu \mathrm{l}$ & $0 \mu \mathrm{l}$ & + \\
\hline 5- FMD P1 cDNA diluted in $\mathrm{H}_{2} \mathrm{O}$ & & $0 \mu \mathrm{l}$ & $0 \mu \mathrm{l}$ & $0 \mu \mathrm{l}$ & $37 \mu \mathrm{l}$ & + \\
\hline 6- FMD P1 cDNA diluted salt & & $0 \mu \mathrm{l}$ & $\left.15 \mu\right|^{\mathrm{a}}$ & $\left.15 \mu\right|^{\mathrm{a}}$ & $7 \mu \mathrm{l}$ & + \\
\hline 7- FMD P1 cDNA control & & $0 \mu \mathrm{l}$ & $0 \mu \mathrm{l}$ & $0 \mu \mathrm{l}$ & $0 \mu l$ & + \\
\hline
\end{tabular}

Samples containing various combinations of FMDV cDNA, SCR, and/or treatment conditions. FMDV sequencing results of $35 \mu \mathrm{FMDV}$ cDNA spanning the P1 coding region of the genome were determined to verify cDNA integrity under different treatment conditions. $\mathrm{NaOH}$ and heat treatment incubation time used in this study was $60 \mathrm{~min}$ as optimized in previous studies. ${ }^{\mathrm{a}} \mathrm{A}$ neutralized salt solution containing equal parts of $\mathrm{NaOH}$ and $\mathrm{HCl}$ was added instead of individual base and acid treatments to serve as a positive control. X indicates $65^{\circ} \mathrm{C}$ for 60 min and 10 min boiling steps were included, and + indicates positive sequencing results

treated samples tested negative for cytopathic effect for FMDV and by immunohistochemical staining for CSFV, suggesting that heat alone was sufficient in making FMDV and CSFV non-infectious (Table 4). All safety treated and heated samples tested negative for cytopathic effect for FMDV and by immunohistochemical staining for CSFV, indicating that the entire safety treatment process (chemical treatment and heat treatment in combination) was successful at inactivating both FMD and CSF viruses (Table 4).

Indeed, earlier studies performed at the USDA, Foreign Animal Disease Diagnostic Laboratory (FADDL) previously established boiling as a method to inactivate a number of animal disease viruses (Table 5; J. A. House, et al., unpublished observations). Viruses tested included
African horse sickness virus (serotype 4), ASFV (Brazil strain), FMDV (O1 Campos), lumpy skin disease virus (Ismalia strain), porcine parvovirus (NVSL strain), rinderpest virus (Kabete $\mathrm{O}$ strain), swine vesicular disease (UK 27/72 strain), vesicular exanthema of swine (serotype A 48), and vesicular stomatitis virus (serotype Indiana 1). Each high titer virus sample was treated by boiling for 5 or $10 \mathrm{~min}$ in culture medium containing 2 to $5 \%$ fetal bovine serum. Infectivity was assessed by in vitro cultivation and titering in Vero, swine kidney cell line (IBRS-2), fetal bovine lung (FBL) or swine testicular cells (ST) depending on the virus. In all instances, boiling for both 5 and $10 \mathrm{~min}$ were found to be effective at eliminating infectivity as assayed by in vitro infectivity assays. This data formed the basis for retaining a $10 \mathrm{~min}$

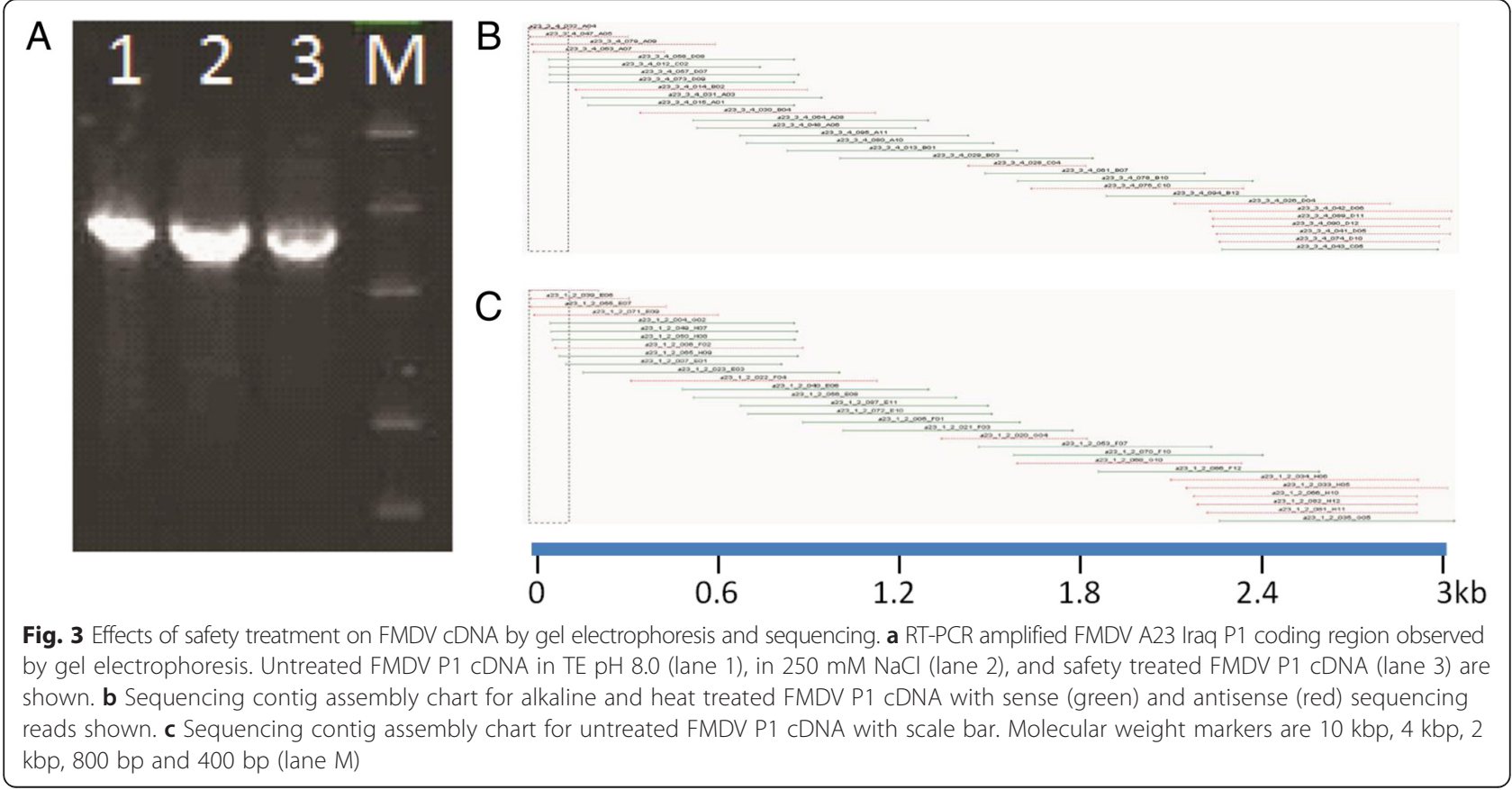


Table 4 Sample composition, treatment and virus infectivity

\begin{tabular}{|c|c|c|c|c|c|c|c|c|}
\hline Sample & $\mathrm{TCID}_{50}$ & $\mathrm{NaOH}$ & $65^{\circ} \mathrm{C}$ Incubation & $\mathrm{NaCl}$ & Post Neutralization Boil & $\mathrm{Vl}$ & FMD rRT-PCR & CSF rRT-PCP \\
\hline 1- FMDV & $6.53 \times 10^{4}$ & - & - & - & - & + & NT & NT \\
\hline 2- CSFV & $4.11 \times 10^{5}$ & - & - & - & - & + & NT & NT \\
\hline 3- FMDV & $3.51 \times 10^{4}$ & - & - & - & - & + & NT & NT \\
\hline 4- CSFV & $2.21 \times 10^{5}$ & - & - & - & - & + & NT & NT \\
\hline 5- FMDV & $3.51 \times 10^{4}$ & - & - & $0.25 \mathrm{~N}^{\mathrm{a}}$ & - & + & NT & NT \\
\hline 6- CSFV & $2.21 \times 10^{5}$ & - & - & $0.25 \mathrm{~N}^{\mathrm{a}}$ & - & + & NT & NT \\
\hline 7- FMDV & $3.51 \times 10^{4}$ & - & - & - & - & + & NT & NT \\
\hline 8- CSFV & $2.21 \times 10^{5}$ & - & - & - & - & + & NT & NT \\
\hline 9- FMDV + SCR & $2.81 \times 10^{4}$ & - & $60 \mathrm{~min}$ & - & $10 \mathrm{~min}$ & - & NT & NT \\
\hline 10- CSFV + SCR & $1.77 \times 10^{5}$ & - & $60 \mathrm{~min}$ & - & $10 \mathrm{~min}$ & - & NT & NT \\
\hline 11- FMDV+ SCR & $2.81 \times 10^{4}$ & $0.25 \mathrm{~N}$ & $60 \mathrm{~min}$ & $0.25 \mathrm{~N}$ & $10 \mathrm{~min}$ & - & NT & NT \\
\hline 12- CSFV + SCR & $1.77 \times 10^{5}$ & $0.25 \mathrm{~N}$ & $60 \mathrm{~min}$ & $0.25 \mathrm{~N}$ & $10 \mathrm{~min}$ & - & NT & NT \\
\hline 13- NEG TE & 0 & - & - & - & - & - & NT & NT \\
\hline 14- NEG Salt & 0 & - & - & $0.25 \mathrm{~N}^{\mathrm{a}}$ & - & - & NT & NT \\
\hline 15- NEG Salt & 0 & - & - & $0.25 \mathrm{~N}^{\mathrm{a}}$ & - & - & NT & NT \\
\hline 16- NEG MEM & 0 & - & - & - & - & - & NT & NT \\
\hline 17- FMDV + SCR & $3.98 \times 10^{6}$ & - & - & - & - & + & + & NT \\
\hline 18- FMDV + SCR & $3.98 \times 10^{6}$ & - & $60 \mathrm{~min}$ & - & - & + & + & NT \\
\hline 19- FMDV + SCR & $3.98 \times 10^{6}$ & - & - & - & $5 \mathrm{~min}$ & - & + & NT \\
\hline 20- FMDV + SCR & $3.98 \times 10^{6}$ & - & - & - & $10 \mathrm{~min}$ & - & + & NT \\
\hline 21- FMDV + SCR & $3.98 \times 10^{6}$ & $0.25 \mathrm{~N}$ & $60 \mathrm{~min}$ at $25^{\circ} \mathrm{C}$ & $0.25 \mathrm{~N}$ & - & - & - & NT \\
\hline 22- FMDV + SCR & $3.98 \times 10^{6}$ & $0.25 \mathrm{~N}$ & $60 \mathrm{~min}$ & $0.25 \mathrm{~N}$ & $10 \mathrm{~min}$ & - & - & NT \\
\hline 23- TE & 0 & - & - & - & - & - & - & NT \\
\hline 24- CSFV + SCR & $2.23 \times 10^{4}$ & - & - & - & - & + & NT & + \\
\hline 25- CSFV + SCR & $2.23 \times 10^{4}$ & - & $60 \mathrm{~min}$ & - & - & + & NT & + \\
\hline 26- CSFV + SCR & $2.23 \times 10^{4}$ & - & - & - & $5 \mathrm{~min}$ & - & NT & + \\
\hline 27- CSFV + SCR & $2.23 \times 10^{4}$ & - & - & - & $10 \mathrm{~min}$ & - & NT & + \\
\hline 28- CSFV + SCR & $2.23 \times 10^{4}$ & $0.25 \mathrm{~N}$ & $60 \mathrm{~min}$ at $25^{\circ} \mathrm{C}$ & $0.25 \mathrm{~N}$ & - & - & NT & + \\
\hline 29- CSFV + SCR & $2.23 \times 10^{4}$ & $0.25 \mathrm{~N}$ & $60 \mathrm{~min}$ & $0.25 \mathrm{~N}$ & $10 \mathrm{~min}$ & - & NT & - \\
\hline 30- TE & 0 & - & - & - & - & - & NT & - \\
\hline
\end{tabular}

Samples containing various combinations of FMDV, CSFV, SCR, and treatment conditions are shown. Virus isolation (VI) results are presented to verify inactivation of infectious FMDV and CSFV under various conditions. The $\mathrm{NaOH}$ and heat treatment incubation time used in this study was the optimized 60 min incubation at $65{ }^{\circ} \mathrm{C}$. ${ }^{2}$ Neutralized salt solution was added instead of $\mathrm{NaOH}$. NT indicates not tested; - indicates negative rRT-PCR result or reagent or condition not added; + indicates positive rRT-PCR result

boiling step following the $\mathrm{NaOH}$ and heat hydrolysis of RNA as an added measure to ensure the inactivation of the above listed animal disease viruses.

\section{Efficacy of alkaline and heat hydrolysis treatment}

After development and formalization of the protocol, the DNA safety treatment procedure was conducted on 15 separate occasions for a total of 80 individual DNA samples. SCR rRT-PCR product was detected in two samples near the limit of detection $(\mathrm{Ct}=38.04$ and 38.15$)$ yielding a specificity of $97.5 \%$ (95 \% CI $\pm 3.42 \%$ ) for hydrolysis of SCR beyond the limit of rRT-PCR detection. Sensitivity of the SCR rRT-PCR was $100 \%$ (99\% CI $\pm 0 \%$ ). DNA safety treatment of the two samples in which SCR was detectable by rRT-PCR was repeated with complete elimination of detectable SCR. Hence to reduce risk to a minimal level, safety treated DNA should not be released from biocontainment without a parallel control sample having a negative SCR rRT-PCR result.

\section{Discussion}

The high impact of an animal disease event associated with the accidental release of high consequence animal disease viruses necessitates the precaution of having 
Table $\mathbf{5}$ Results of inactivation of selected viruses by boiling

\begin{tabular}{|c|c|c|c|c|c|c|}
\hline \multirow[t]{2}{*}{ Virus Species } & \multirow[t]{2}{*}{ Virus Genus (Family) } & \multirow[t]{2}{*}{ Cell Line } & \multirow[t]{2}{*}{ Days of Incubation } & \multicolumn{3}{|c|}{ Virus Titers and Boiling Times (Log base 10 of $\mathrm{TCID}_{50} \mathrm{ml}^{-1}$ ) } \\
\hline & & & & $0 \mathrm{~min}$ & $5 \mathrm{~min}$ & $10 \mathrm{~min}$ \\
\hline $\begin{array}{l}\text { African horse sickness virus } \\
\text { (Serotype 4) }\end{array}$ & $\begin{array}{l}\text { Orbivirus } \\
\text { (Reoviridae) }\end{array}$ & Vero & 10 & 7.7 & nvd & nvd \\
\hline $\begin{array}{l}\text { African swine fever virus } \\
\text { (Brazil strain) }\end{array}$ & $\begin{array}{l}\text { Asfivirus } \\
\text { (Asfarviridae) }\end{array}$ & Vero & 10 & 5.9 & nvd & nvd \\
\hline $\begin{array}{l}\text { Foot-and-mouth disease virus } \\
\text { (O1 Campos) }\end{array}$ & $\begin{array}{l}\text { Apthovirus } \\
\text { (Picornaviridae) }\end{array}$ & IBRS-2 & 3 & 7.5 & nvd & nvd \\
\hline $\begin{array}{l}\text { Lumpy skin disease virus } \\
\text { (Ismalia strain) }\end{array}$ & $\begin{array}{l}\text { Capripoxvirus } \\
\text { (Poxviridae) }\end{array}$ & FBL & 13 & 7.9 & nvd & nvd \\
\hline $\begin{array}{l}\text { Porcine parvovirus } \\
\text { (NVSL strain) }\end{array}$ & $\begin{array}{l}\text { Protoparvovirus } \\
\text { (Parvovirinae) }\end{array}$ & ST & 10 & 5.9 & nvd & nvd \\
\hline $\begin{array}{l}\text { Rinderpest virus } \\
\text { (Kabete O strain) }\end{array}$ & $\begin{array}{l}\text { Morbillivirus } \\
\text { (Paramyxoviridae) }\end{array}$ & Vero & 9 & 6.4 & nvd & nvd \\
\hline $\begin{array}{l}\text { Swine vesicular disease } \\
\text { (UK } 27 / 72 \text { strain) }\end{array}$ & $\begin{array}{l}\text { Enterovirus } \\
\text { (Picornaviridae) }\end{array}$ & IBRS-2 & 3 & 6.8 & nvd & nvd \\
\hline $\begin{array}{l}\text { Vesicular exanthema of swine } \\
\text { (Serotype A 48) }\end{array}$ & $\begin{array}{l}\text { Vesivirus } \\
\text { (Caliciviridae) }\end{array}$ & Vero & 3 & 8.9 & nvd & nvd \\
\hline $\begin{array}{l}\text { Vesicular stomatitis virus } \\
\text { (Serotype Indiana 1) }\end{array}$ & $\begin{array}{l}\text { Vesiculovirus } \\
\text { (Rhabdoviridae) }\end{array}$ & Vero & 3 & 5.8 & nvd & nvd \\
\hline
\end{tabular}

No virus detected (nvd); African green monkey kidney cell line (Vero); swine kidney cell line (IBRS-2); fetal bovine lung (FBL); swine testicular cell line (ST); J. A. House, et al., unpublished observations

procedures to ensure the complete inactivation of viruses and + ssRNA viral genomes. In the studies presented here, boiling alone for five minutes was demonstrated to inactivate African horse sickness virus, African swine fever virus, foot-and-mouth disease virus, lumpy skin disease virus, porcine parvovirus, swine vesicular disease virus, vesicular exanthema of swine virus, classical swine fever virus, and vesicular stomatitis virus (Tables 4 and 5), and alkaline and heat treated samples spiked with FMDV and CSFV likewise demonstrated loss of virus infectivity in vitro (Table 4). The presented procedure relies not only on hot alkaline conditions $(0.25 \mathrm{~N}$ $\mathrm{NaOH}$ and $65{ }^{\circ} \mathrm{C}$ for $1 \mathrm{~h}$ ) for the degradation of all RNA, presumably to free ribonucleotides with 5'-hydroxyls and 3'-phosphates, but also on the additional step of boiling at $100{ }^{\circ} \mathrm{C}$ for $10 \mathrm{~min}$ after $\mathrm{pH}$ has been neutralized to between $\mathrm{pH} 7$ and 8. As even a few breaks in viral genomic RNA are likely to prevent reconstitution of infectious virus, the standard of complete loss of rRT-PCR detectable SCR may appear to be an overly stringent assessment for verification of the DNA safety treatment procedure. Admittedly, the risk of animal infection or accidental reconstitution and release of a virus from RNA contaminants of purified DNA is extremely low. Published examples of + ssRNA viruses reconstituted in animals are few and typically involve direct injection of highly purified and abundant in vitro transcribed viral RNA within a cellular transfection medium such as lipofectamine $[19,20]$. In vitro, also using cell transfection methods, recovery of virus from
RNA is more common; though, RNA needs to be of high quality, presumably with few or no breaks within protein coding or regulatory elements $[19,21,22]$. It is hoped that the stringent measure of RNA degradation employed herein will add confidence in the safety of exported DNA from laboratories that work with highly infectious animal disease viruses of national and international economic impact such as FMDV.

It is also hoped that the alkaline and heat treatment procedure will improve the quality of DNA over other methods of DNA safety treatment such as RNAse A treatment [23]. In this regard, $\mathrm{NaOH}$ and heat treatment are expected to provide more effective degradation of protein and/or lipid encapsulated RNA as well as RNA within an RNA:RNA or RNA:DNA duplex. Indeed, similar treatments with $\mathrm{NaOH}$ and heat have been found to be effective in removal of RNA from cDNA preparations used in transcriptome analyses using quantitative RTPCR or microarrays $[10,11]$.

\section{Conclusions}

Although denaturation of dsDNA to ssDNA and/or nicking of supercoiled plasmid DNA to relaxed covalently closed structures is anticipated from both alkaline and heat treatment, results of all experiments presented in this summary demonstrated maintenance of integrity of the DNA suitable for routine molecular biology manipulations including PCR, rPCR, DNA sequencing, and bacterial transformations. However, evaluation of safety treated DNA for the potential accumulation of mutations due to 
error-prone DNA repair following introduction of treated DNA to eukaryotic cells or to diverse strains of E.coli has yet to be undertaken. One should anticipate a potential one to two log reduction in efficiency of bacterial transformations using alkaline and heat treated plasmids, and while treated DNA may be used directly for transforming chemically competent $E$. coli, it must be desalted prior to bacterial transformation by electroporation. Incorrect neutralization of the alkaline conditions represents a notable pitfall in the DNA safety treatment procedure. This may lead to autocatalytic depurination, DNA nicking, dsDNA breaks or complete degradation of DNA if the neutralization step is incorrectly performed, resulting in acidic condition. To mitigate this, the procedure includes a pH check of quality critical $\mathrm{NaOH}$ and $\mathrm{HCl}$ reagents. Despite these potential technical pitfalls, alkaline and heat hydrolysis to remove RNA from purified DNA represents an attractive option for the safe sharing of DNA between biocontainment laboratories that work with + ssRNA viruses.

\section{Methods}

$\mathrm{NaOH}$ and heat safety treatment of purified DNA

Plasmid and other DNA samples $\leq 5 \mathrm{mg} / \mathrm{ml}$ buffered with $\leq 100 \mathrm{mM}$ Tris $\mathrm{pH} 8.0$ or standard TE $\mathrm{pH} 8.0$ are suitable for alkaline and heat safety treatment. The DNA safety treatment is conducted in three phases. First, potential contaminating viral or bacterial agents and viral positive sense genomic RNA that may be infectious is destroyed by $1 \mathrm{~h}$ heat $\left(65{ }^{\circ} \mathrm{C}\right.$ and alkali treatment at $0.25 \mathrm{~N}$ sodium hydroxide $(\mathrm{pH}>12)$. Second, sample $\mathrm{pH}$ is neutralized with equi-normal $\mathrm{HCl}$ to ensure usefulness of DNA in downstream molecular biology applications. Third, any potential contaminating virus present is inactivated by boiling at $100{ }^{\circ} \mathrm{C}$ for $10 \mathrm{~min}$. Samples are slow cooled to room temperature for $20 \mathrm{~min}$ to renature DNA prior to being stored frozen. Treated sample tubes must remain closed after the neutralization step and throughout the boiling step until exported from the biocontainment lab to prevent potential post-treatment contamination.

Prior to the treatment procedure, reagents are quality control checked for proper neutralization. Briefly, 2.33 parts by volume of TE buffer ( $\mathrm{pH} 8.0$ ), 1 part by volume $1 \mathrm{~N} \mathrm{NaOH}$ and 1 part by volume of $1 \mathrm{~N} \mathrm{HCl}$ are combined and mixed gently. The solution is tested with a $\mathrm{pH}$ meter or $\mathrm{pH}$ strips to ensure a proper neutralized $\mathrm{pH}$ between 7 and 8 .

SCR was developed as an internal control to ensure proper degradation of contaminating RNA before exportation from a containment laboratory. The SCR was spiked into a parallel sample that was $1 / 5$ the volume of the primary sample. Treatment of this parallel control sample is performed in the same manner with the same proportions of $\mathrm{NaOH}$ and $\mathrm{HCl}$ reagents and is tested by
rRT-PCR for SCR detection along with an untreated SCR positive control to ensure proper performance of the procedure and effective degradation of any potentially contaminating RNA.

\section{Cells and viruses}

All cell lines were supplied by the Reagent and Vaccine Services Section (RVSS) of the USDA National Veterinary Services Laboratories' (NVSL) FADDL located at the Plum Island Animal Disease Center (PIADC). Swine kidney-6 (SK-6), primary lamb kidney (LK), and African green monkey (Vero) cells were grown in Eagle's minimum essential medium (EMEM) supplemented with $10 \%$ fetal bovine serum and incubated at $37{ }^{\circ} \mathrm{C}, 5 \%$ $\mathrm{CO}_{2}$, and $100 \%$ humidity. Earlier studies (J. A. House, et al., unpublished observations) conducted in 1994 (Table 5), to assess infectivity of various viruses after boiling for 5 and $10 \mathrm{~min}$, utilized Vero, swine kidney cell line (IBRS-2), and primary fetal bovine lung (FBL), and swine testicular cell line (ST) cultured under similar conditions. Virus inocula including African horse sickness virus (serotype 4), African swine fever virus (Brazil strain), FMDV (O1 Campos), lumpy skin disease virus (Ismalia strain), porcine parvovirus (NVSL strain), rinderpest virus (Kabete $\mathrm{O}$ strain), swine vesicular disease (UK 27/72 strain), vesicular exanthema of swine (serotype A 48), and vesicular stomatitis virus (serotype Indiana 1) were treated by boiling for 5 or $10 \mathrm{~min}$ in culture medium containing 2 to $5 \%$ fetal bovine serum.

Viruses were supplied by the RVSS repository of the FADDL. FMDV stocks were propagated in primary LK cells. A cell monolayer greater than $80 \%$ confluent was infected with FMDV C4 Tierra del Fuego $\left(1.0 \times 10^{7}\right.$ $\left.\mathrm{TCID}_{50} / \mathrm{ml}\right)$ or FMDV O Venezuela $\left(2.51 \times 10^{5} \mathrm{TCID}_{50} /\right.$ $\mathrm{ml}$ ) and observed for cytopathic effects (CPE) for a maximum of $72 \mathrm{~h}$. Flasks were placed in a $-70{ }^{\circ} \mathrm{C}$ freezer when greater than $80 \%$ of the monolayer displayed CPE. Virus infected LK cultures were freeze-thawed, harvested, and stored frozen at $-70{ }^{\circ} \mathrm{C}$. Virus titrations were performed in 96-well plates using the Spearman- Kärber $50 \%$ tissue culture method [24]. CSFV stocks were propagated in SK-6 cells. A cell monolayer greater than $70 \%$ confluent was infected with CSFV Brescia (1.12 x $\left.10^{6} \mathrm{TCID}_{50} / \mathrm{ml}\right)$ or CSFV Kanagawa $\left(1.58 \times 10^{6} \mathrm{TCID}_{50} /\right.$ $\mathrm{ml}$ ), incubated for $72 \mathrm{~h}$, and subjected to a freeze thaw prior to harvesting and storing at $-70{ }^{\circ} \mathrm{C}$. Virus titrations were performed in 24-well plates and immunohistochemistry was performed using the VECTASTAIN ${ }^{\circ}$ $\mathrm{ABC}$-AP KIT according to the manufacturer instructions. ASFV Killean III $\left(6.31 \times 10^{7} \mathrm{TCID}_{50} / \mathrm{ml}\right)$ strain was propagated in swine macrophage cells and observed for hemadsorption (rosette formation) for a maximum of 10 days. Flasks were freeze thawed, aliquotted, and frozen at $-70{ }^{\circ} \mathrm{C}$ until use. The $50 \%$ tissue culture 
infectious dose using the Spearman-Kärber method was used to calculate titrations [24].

ASFV was grown in primary cultures of peripheral blood macrophages collected from a donor pig. Swine macrophages were isolated from fresh whole swine blood using a Ficoll-paque gradient and centrifugation to separate the three phases: plasma, white blood cells (buffy coat) and red blood cells. The buffy coat fraction was then isolated and washed several times in RPMI/ $1 \%$ antibiotic media and plated in PRIMARIA ${ }^{\mathrm{mm}}$ coated culture flasks. Macrophages were concentrated and replated prior to infection and each lot was isolated fresh for each infection. All cell lines were sterility and virus sensitivity tested.

\section{Virus isolation of safety treated samples}

Virus isolation was performed to ensure inactivation of FMDV and CSFV during the $\mathrm{NaOH}$ and heat DNA safety treatment process. Starting titers for different stocks of FMDV O Venezuela V3205 and CSFV Kanagawa V2861 were $2.51 \times 10^{5} \mathrm{TCID}_{50} / \mathrm{ml}$ or $3.55 \times 10^{7} \mathrm{TCID}_{50} / \mathrm{ml}$ and $1.58 \times 10^{6} \mathrm{TCID}_{50} / \mathrm{ml}$ or $1.99 \times 10^{5} \mathrm{TCID}_{50} / \mathrm{ml}$, respectively. $\mathrm{NaOH}$ and/or heat treatments were performed as described below. Heating steps included incubation at $65{ }^{\circ} \mathrm{C}$ for $1 \mathrm{~h}$ and boiling at $100{ }^{\circ} \mathrm{C}$ for $10 \mathrm{~min}$. Various concentrations of virus in diluents, TE or $0.23 \mathrm{M} \mathrm{NaCl}$ (salt), representing the final salt concentration of neutralized $\mathrm{NaOH}$ treated samples, were tested with or without heating. FMDV or CSFV infectivity was assessed by in vitro cultivation in susceptible cells in EMEM supplemented with $4 \% \mathrm{FBS}$ at $37{ }^{\circ} \mathrm{C}, 5 \% \mathrm{CO}_{2}$, and $100 \%$ humidity. FMDV infectivity was assessed by cultivation in primary LK cells in $25 \mathrm{~cm}^{2}$ polystyrene tissue culture treated flasks. LK cells, approximately $80 \%$ confluent, were inoculated with $260 \mu \mathrm{l}$ of each FMDV containing sample and observed every $24 \mathrm{~h}$ post inoculation for evidence of cytopathic effects (CPE). CPE negative flasks were observed for a total of $96 \mathrm{~h}$ followed by freeze-thaw and second passage on LK cells for an additional $96 \mathrm{~h}$ to ensure the absence of infectious FMDV. CSFV infectivity was assessed by cultivation in SK-6 cells. SK-6 cells, approximately $70 \%$ confluent, were inoculated with $100 \mu \mathrm{l}$ of each CSFV containing sample in duplicate wells of a 24-well polystyrene tissue culture plate. At $72 \mathrm{~h}$ post inoculation, monolayers were fixed in $60 \%$ acetone and $40 \%$ methanol at $-20{ }^{\circ} \mathrm{C}$ for $10 \mathrm{~min}$ and stained using the VECTASTAIN ${ }^{\circ}$ ABC-AP KIT according to the manufacturer instructions. Stained monolayers were evaluated microscopically to determine presence or absence of infectious CSFV.

\section{Nucleic acids}

RNA extractions for FMDV and CSFV were performed using the RNeasy ${ }^{\circ}$ Mini Kit (Qiagen, Valencia, CA, USA) and DNA extractions for ASFV were performed using the DNeasy ${ }^{\circ}$ Blood and Tissue Kit (Qiagen, Valencia, CA, USA) according to manufacturer's instructions. The pGEM-T Easy vector plasmid (Promega Corp.) was propagated in overnight cultures of transformed JM109 or TOP10 E.coli in LB medium containing $100 \mu \mathrm{g} \mathrm{ml}^{-1}$ ampicillin. The pBlueScript II plasmid (Agilent Technologies) was similarly propagated in E.coli DH5 alpha. Plasmids were purified using the Qiagen QIAquick Spin Miniprep PCR Purification Kit as per manufacturer's instructions. Plasmid preparations were quantified on a NanoDrop 2000 spectrophotometer and stored frozen at $-30{ }^{\circ} \mathrm{C}$.

An internal 199 bp synthetic control RNA (SCR), designed partially from the bacteriophage $\mathrm{Q}$ beta, was purchased from IDT (sequence: UCUUAAGUCGAUAAA UGCUUAUUGCUCUCUUAGCACUGGGUUUUACAA ACCUGUGGAUGGCGUGAUAGUUGGCUUUUGGC GCGAUCCAUCCAUCCUUUGCACGCCGUGGGACG ACUUCACUGCGAGUCCUGCCACGGAGUCCUAUU CAAGCCGUGAUAGUCGUUCCUCGUGCUUAGUAA CUAAGGAUGAAAUGCAUGUC). The SCR was incorporated into parallel safety treatments of split samples to ensure proper degradation of contaminating RNA before exportation from a containment laboratory. Specific primer and probe binding sites were included in the sequence of the SCR for rRT-PCR detection. The SCR was diluted in TE buffer ( $\mathrm{pH}$ 8.0) and used at a concentration of $6 \times 10^{-6} \mathrm{ng} \mathrm{ml}^{-1}$, which yields a cycle threshold (Ct) value of 30 in rRT-PCR.

Qualitative evaluations of plasmid DNA and PCR products before and after treatments were performed electrophoresis in $2 \%$ agarose gels using the E-Gel Electrophoresis System (Thermo Fisher Scientific),

\section{Bacterial transformations}

Transformation efficiencies for alkali and heat treated DNA were evaluated using competent $E$. coli DH5 alpha (Invitrogen-Thermo Fisher Scientific), JM109 and BL21(DE3) pLys S (Promega), and 60 ng alkali and heat treated pBlueScript II plasmid (Agilent Technologies) or untreated plasmid as control. Bacterial transformations were performed using a variation of the heat shock method described previously [18], prior to plating on LB agar containing $100 \mu \mathrm{g} \mathrm{ml}^{-1}$ ampicillin, $80 \mu \mathrm{g} \mathrm{ml}^{-1} \mathrm{X}$ gal, and $50 \mathrm{mM}$ IPTG (Teknova). Expression and function of the $L a c Z$ gene product from pBlueScript II was evaluated by blue white screening of DH5 alpha colonies, and transformation efficiencies were calculated in colony forming units per $\mu \mathrm{g}$ of plasmid.

\section{Real-time and conventional PCR and RT-PCR}

Real-time RT-PCR was performed to optimize the $\mathrm{NaOH}$ safety treatment method and to evaluate SCR degradation, CSF RNA degradation, CSF DNA integrity, 
and ASF DNA integrity after $\mathrm{NaOH}$ and heat safety treatment, heat treatment alone, and no treatment as a control.

RNA samples were amplified using the GeneAmp ${ }^{\circ} \mathrm{EZ}$ rTth RNA PCR kit (Life Technologies, Grand Island, NY, USA) and a SmartCycler II (Cepheid, Sunnyvale, CA) with automatic background subtraction on, or using the TaqMan Fast Virus 1-Step Master Mix (Life Technologies, Grand Island, NY, USA) and an Applied Biosystems ${ }^{\bullet} 7500$ Real-Time PCR System (Life Technologies, Grand Island, NY, USA). The SCR RT-PCR reactions each consisted of $0.2 \mu \mathrm{M}$ of each primer, $0.1 \mu \mathrm{M}$ of FAM/TAMRA probe, $5 \mu \mathrm{l}$ of $5 \mathrm{x}$ GeneAmp ${ }^{\circ} \mathrm{EZ}$ Buffer, $5 \mathrm{mM}$ of $\mathrm{Mn}(\mathrm{OAc})_{2}$, $1.2 \mathrm{mM}$ of dNTP mix, $1 \mu \mathrm{l}$ of rTth DNA polymerase, and $2.5 \mu \mathrm{l}$ of RNA template in a final reaction volume of $25 \mu \mathrm{l}$. The thermal profile consisted of reverse transcription at $60{ }^{\circ} \mathrm{C}$ for $10 \mathrm{~min}$, followed by 45 cycles of $95^{\circ} \mathrm{C}$ for $2 \mathrm{~s}$ and $60{ }^{\circ} \mathrm{C}$ for $30 \mathrm{~s}$. Primer and probe sequences include SCR forward primer: 5'ACTGGGTTTTACAAACCTGTGA -3', SCR reverse primer: 5'- TCCGTGGCAGGACTCGC -3', and SCR probe: 6FAM-TCCTTTGCACGCCGTGG GAC-TAMRA. A result cut-off, above a manual fluorescence threshold of 30, was defined as positive at $\mathrm{Ct} \leq 40$, inconclusive at $\mathrm{Ct}>40$, and negative if no $\mathrm{Ct}$ was observed.

After discontinuation of the GeneAmp EZ rTth RNA PCR reagents by Life Technologies, a brief methods comparison study was performed using the TaqMan ${ }^{\circ}$ Fast Virus 1-Step Master Mix (Life Technologies, Grand Island, NY, USA) to ensure reagent sensitivity similar to the tested method. SCR rRT-PCR consisted of $0.2 \mu \mathrm{M}$ of each primer, $0.1 \mu \mathrm{M}$ of FAM/TAMRA probe, $6.25 \mu \mathrm{l}$ of $4 \times 1$-Step Master Mix and $2.5 \mu \mathrm{l}$ sample in a final reaction volume of $25 \mu \mathrm{l}$. The thermal profile consisted of reverse transcription at $50{ }^{\circ} \mathrm{C}$ for $5 \mathrm{~min}$ and initial denaturation at $95{ }^{\circ} \mathrm{C}$ for $20 \mathrm{~s}$, followed by 45 cycles of $95{ }^{\circ} \mathrm{C}$ for $15 \mathrm{~s}$ and $60{ }^{\circ} \mathrm{C}$ for $1 \mathrm{~min}$.

CSFV RNA and CSFV DNA spiked pGEM Teasy vector plasmid DNA samples were amplified after $\mathrm{NaOH}$ and heat treatment, heat treatment alone, and no treatment as a control. Samples were amplified using the GeneAmp ${ }^{\circ}$ EZ rTth RNA PCR kit (Life Technologies, Grand Island, NY, USA). The CSF rRT-PCR reactions each consisted of $0.2 \mu \mathrm{M}$ of each primer, $0.1 \mu \mathrm{M}$ of FAM/MGB probe, $5 \mu \mathrm{l}$ of $5 \mathrm{x}$ GeneAmp ${ }^{\circ}$ EZ Buffer and $2.5 \mu \mathrm{l}$ sample in a final reaction volume of $25 \mu \mathrm{l}$. The thermal profile consisted of reverse transcription at $60{ }^{\circ} \mathrm{C}$ for $10 \mathrm{~min}$, followed by 45 cycles of $95{ }^{\circ} \mathrm{C}$ for $2 \mathrm{~s}$ and $60{ }^{\circ} \mathrm{C}$ for $30 \mathrm{~s}$ [25].

After discontinuation of the GeneAmp ${ }^{\circ}$ EZ rTth RNA PCR reagents by Life Technologies, subsequent FMDV and CSFV RNA samples were amplified using the PathID $^{\text {ma }}$ Multiplex One-Step Kit (Life Technologies, Grand Island, NY, USA). FMD rRT-PCR reactions consisted of $0.2 \mu \mathrm{M}$ of each primer, $0.1 \mu \mathrm{M}$ of FAM/TAMRA probe
[26], $12.5 \mu \mathrm{l}$ of 2x Multiplex RT-PCR buffer, $2.5 \mu \mathrm{l}$ of 10x Multiplex enzyme mix and $2.5 \mu \mathrm{l}$ sample in a final reaction volume of $25 \mu \mathrm{l}$. The thermal profile consisted of reverse transcription at $48{ }^{\circ} \mathrm{C}$ for $10 \mathrm{~min}, 95{ }^{\circ} \mathrm{C}$ for $10 \mathrm{~min}$, followed by 45 cycles of $95{ }^{\circ} \mathrm{C}$ for $2 \mathrm{~s}$ and $60{ }^{\circ} \mathrm{C}$ for $40 \mathrm{~s}$ using the FAST mode on the Applied Biosystems $^{\circ} 7500$ Real-Time PCR System (Life Technologies, Grand Island, NY, USA). CSF rRT-PCR reactions consisted of $0.2 \mu \mathrm{M}$ forward primer, $0.4 \mu \mathrm{M}$ reverse primer, $0.2 \mu \mathrm{M}$ of FAM/MGB probe [25], $12.5 \mu \mathrm{l}$ of $2 \mathrm{x}$ Multiplex RT-PCR buffer, $2.5 \mu \mathrm{l}$ of 10x Multiplex enzyme mix and $2.5 \mu \mathrm{l}$ sample in a final reaction volume of $25 \mu \mathrm{l}$ using the same thermal profile and platform as described above for FMD rRT-PCR.

ASF DNA spiked pGEM Teasy vector plasmid DNA samples were amplified after $\mathrm{NaOH}$ treatment and heat treatment, heat treatment alone, and no treatment as a control. Samples were amplified using the TaqMan ${ }^{\circ}$ EZ RT-PCR kit (Life Technologies, Grand Island, NY, USA). The ASF qPCR reactions consisted of $0.3 \mu \mathrm{M}$ of each primer, $0.2 \mu \mathrm{M}$ of FAM/MGB probe, $5 \mu \mathrm{l}$ of $5 \mathrm{x}_{\text {TaqMan }}{ }^{\circ}$ EZ Buffer and $2.5 \mu \mathrm{l}$ sample in a final reaction volume of $25 \mu$ l. The thermal profile consisted of 45 cycles of $95{ }^{\circ} \mathrm{C}$ for $2 \mathrm{~s}$ and $60{ }^{\circ} \mathrm{C}$ for $30 \mathrm{~s}$ [27]. All rRT-PCR reactions were performed on the SmartCycler II PCR platform (Cepheid, Sunnyvale, CA, USA). Conventional RTPCR of the $3 \mathrm{~kb}$ capsid coding P1 region of the FMDV genome was performed as previously described [28].

\section{FMDV cDNA sequencing}

The FMDV P1 RT-PCR product was purified using a QIAquick ${ }^{\circ}$ PCR Purification kit (Qiagen) according to manufacturer's instructions. Purified FMDV cDNA was quantified using a NanoDrop 2000 spectrophotometer (Fisher Scientific, Pittsburg, PA, USA) and sequenced in $10 \mu \mathrm{l}$ reactions containing $2 \mu \mathrm{l}$ of BigDye ${ }^{\circ}$ Terminator v3.1 (Applied Biosystems), 5 pmol of primer, and $15 \mathrm{ng}$ of purified RT-PCR product as previously described [28]. Thermal cycling conditions consisted of 35 cycles of $10 \mathrm{~s}$ at $96{ }^{\circ} \mathrm{C}, 5 \mathrm{~s}$ at $50{ }^{\circ} \mathrm{C}$, followed by $4 \mathrm{~min}$ at $60{ }^{\circ} \mathrm{C}$. Sequencing products were purified on a Kingfisher 96 magnetic particle processor (Thermo Fisher Scientific) using a high-throughput the CleanSEQ kit (Agencourt). Nucleotide sequences were resolved using a 3730XL DNA sequencer (Applied Biosystems), and sequence contigs for each sample were compiled using the Sequencher ${ }^{\circ}$ software (Gene Codes).

\footnotetext{
Abbreviations

+ssRNA, positive - sense single stranded RNA; ASFV, African swine fever virus; CSF, classical swine fever virus; dsDNA, double-stranded DNA; FBL, fetal bovine lung; FMDV, foot-and-mouth disease virus; IBRS-2, swine kidney cell line; rRT$P C R$, real-time Reverse-transcriptase polymerase chain reaction; SCR, synthetic control RNA; ssDNA, single-stranded DNA; ST, swine testicular cell line; Vero, African green monkey kidney cell line; VI, virus isolation
} 


\section{Acknowledgements}

Data on inactivation of viruses by boiling was kindly provided by the FADDL under direction of Dr. James A. House. This work was supported by a USDA APHIS NVSL graduate training program award to KAL.

\section{Authors' contributions}

KAL conducted most of the experiments, developed the procedure and SCR rRT-PCR assay and drafted the manuscript. YR evaluated the procedure to determine efficacy, sensitivity and specificity of the rRT-PCR verification test. MTM provided overall project design and coordination, assisted in experimental designs and writing the manuscript. All authors read and approved the final manuscript.

\section{Competing interests}

The authors declare that they have no competing interests.

Received: 22 February 2016 Accepted: 30 May 2016

Published online: 04 June 2016

\section{References}

1. OIE. Foot and Mouth Disease, Manual of Diagnostic Tests and Vaccines for Terrestrial Animals. 7th ed. Paris: Office International des Epizooties; 2012. p. Chapter 2.1.5.

2. Jamal SM, Belsham GJ. Foot-and-mouth disease: past, present and future. Vet Res. 2013;44:116. doi:10.1186/1297-9716-44-116.

3. OIE. Classical Swine Fever (hog cholera), Manual of Diagnostic Tests and Vaccines for Terrestrial Animals. 7th ed. Paris: Office International des Epizooties; 2012. p. Chapter 2.8.3.

4. Beer M, Goller KV, Staubach C, Blome S. Genetic variability and distribution of Classical swine fever virus. Anim Health Res Rev. 2015;16(1):33-9. doi:10.1017/S1466252315000109.

5. Gamarnik AV, Andino R. Switch from translation to RNA replication in a positive-stranded RNA virus. Genes Dev. 1998;12(15):2293-304.

6. Clancy S. Chemical Structure of RNA. Nat Educ. 2008;7(1):60

7. Satoh $\mathrm{K}$, Inoue $\mathrm{Y}$. Ion-exchangechrmtography of a dinucleotide preparation from controlled alkaline hydrolysis of ribonucleic acids. Biochem J. 1969; 114(2):271-7.

8. Mauger F, Bauer K, Calloway CD, Semhoun J, Nishimoto T, Myers TW, et al. DNA sequencing by MALDI-TOF MS using alkali cleavage of RNA/DNA chimeras. Nucleic Acids Res. 2007;35(8):e62. doi:10.1093/nar/gkm056.

9. Perou CM, Sorlie T, Eisen MB, van de Rijn M, Jeffrey SS, Rees CA, et al. Molecular portraits of human breast tumours. Nature. 2000;406(6797):74752. doi:10.1038/35021093.

10. Hu Z, Troester M, Perou CM. High reproducibility using sodium hydroxide-stripped long oligonucleotide DNA microarrays. BioTechniques. 2005:38(1):121-4.

11. Libus J, Storchova H. Quantification of cDNA generated by reverse transcription of total RNA provides a simple alternative tool for quantitative RT-PCR normalization. BioTechniques. 2006;41(2):156-8. 60 passim.

12. Birnboim HC, Doly J. A rapid alkaline extraction procedure for screening recombinant plasmid DNA. Nucleic Acids Res. 1979;7(6):1513-23.

13. Champoux JJ, Gilboa E, Baltimore D. Mechanism of RNA primer removal by the RNase $\mathrm{H}$ activity of avian myeloblastosis virus reverse transcriptase. J Virol. 1984;49(3):686-91.

14. OIE. Foot and Mouth Disease. http://www.oie.int/fileadmin/Home/eng/ Animal_Health_in_the_World/docs/pdf/Disease_cards/FOOT_AND_ MOUTH_DISEASE.pdf. Accessed May 172016.

15. OIE. Classical Swine Fever. http://www.oie.int/fileadmin/Home/eng/Animal_ Health_in_the_World/docs/pdf/Disease_cards/CLASSICAL_SWINE_FEVER.pdf. Accessed May 172016.

16. OIE. Disease Cards. http://www.oie.int/animal-health-in-the-world/technicaldisease-cards/. Accessed May 172016.

17. IFAH-Europe. Viral inactivation related to steam sterilisation of biological products. 2012. http://www.ifaheurope.org/component/attachments/ attachments/654.html?task=download. Accessed 17 May 2016.

18. Sambrook J, Maniatis T, Fritsch EF. Molecular cloning : a laboratory manual. 2nd ed. Cold Spring Harbor, N.Y: Cold Spring Harbor Laboratory Press; 1989.

19. Parn K, Viru L, Lehto T, Oskolkov N, Langel U, Merits A. Transfection of infectious RNA and DNA/RNA layered vectors of semliki forest virus by the cell-penetrating peptide based reagent PepFect6. PLoS One. 2013;8(7): e69659. doi:10.1371/journal.pone.0069659.
20. Lv JL, Zhang YG, Wang YL, Pan L, Liu LK, Jiang ST, et al. [Construction and identification of infectious molecular clone of foot-and-mouth disease virus strain O/CHINA/99]. Bing Du Xue Bao. 2009;25(1):58-62.

21. Hiramatsu N, Dash S, Gerber MA. HCV cDNA transfection to HepG2 cells. J Viral Hepat. 1997;4 Suppl 1:61-7.

22. Bisht P, Mohapatra JK, Subramaniam S, Das B, Pande V, Biswal JK, et al. Efficient rescue of foot-and-mouth disease virus in cultured cells transfected with RNA extracted from clinical samples. J Virol Methods. 2014;196:65-70. doi:10.1016/j.jviromet.2013.10.041.

23. Dona F, Houseley J. Unexpected DNA loss mediated by the DNA binding activity of ribonuclease A. PLoS One. 2014;9(12):e115008. doi:10.1371/journal. pone.0115008.

24. House C, House JA. Evaluation of techniques to demonstrate foot-andmouth disease virus in bovine tongue epithelium: comparison of the sensitivity of cattle, mice, primary cell cultures, cryopreserved cell cultures and established cell lines. Vet Microbiol. 1989;20(2):99-109.

25. Risatti GR, Callahan JD, Nelson WM, Borca MV. Rapid detection of classical swine fever virus by a portable real-time reverse transcriptase PCR assay. J Clin Microbiol. 2003;41(1):500-5.

26. Callahan JD, Brown F, Osorio FA, Sur JH, Kramer E, Long GW, et al. Use of a portable real-time reverse transcriptase-polymerase chain reaction assay for rapid detection of foot-and-mouth disease virus. J Am Vet Med Assoc. 2002 220(11):1636-42.

27. Zsak L, Borca MV, Risatti GR, Zsak A, French RA, Lu Z, et al. Preclinical diagnosis of African swine fever in contact-exposed swine by a real-time PCR assay. J Clin Microbiol. 2005:43(1):112-9. doi:10.1128/JCM.43.1.112-119.2005.

28. Xu L, Hurtle W, Rowland JM, Casteran KA, Bucko SM, Grau FR, et al. Development of a universal RT-PCR for amplifying and sequencing the leader and capsid-coding region of foot-and-mouth disease virus. J Virol Methods. 2013;189(1):70-6. doi:10.1016/j.jviromet.2013.01.009.

\section{Submit your next manuscript to BioMed Central and we will help you at every step:}

- We accept pre-submission inquiries

- Our selector tool helps you to find the most relevant journal

- We provide round the clock customer support

- Convenient online submission

- Thorough peer review

- Inclusion in PubMed and all major indexing services

- Maximum visibility for your research

Submit your manuscript at www.biomedcentral.com/submit
) Biomed Central 